\title{
KINETIKA FERMENTASI LIMBAH KULIT NANAS DAN PRODUKTIVITAS ETANOL
}

\author{
Alice Pramashinta ${ }^{\mathrm{a}}$, Abdullah ${ }^{\mathrm{a}}$ \\ ${ }^{a} J u r u s a n$ Teknik Kimia, Fakultas Teknik, Universitas Diponegoro, Semarang, Indonesia \\ J1. Prof Sudharto Tembalang Semarang \\ Email : alicepramashinta@gmail.com
}

\begin{abstract}
In this research studied the effect of initial total sugar concentration of pineapple peel waste in cell concentration, total sugar consumption and ethanol production profile. Pineapple peel fermentation is done by batch system for 60 hours with various intial total sugar 30, 50 and $70 \mathrm{~g} / \mathrm{L}$. Batch fermentation profiles showed that the optimum total sugar concentration was $70 \mathrm{~g} / \mathrm{L}$ which resulted highest ethanol productivity $0.617 \mathrm{~g} / \mathrm{L} / \mathrm{h}$ when compared with total sugar concentration $30 \mathrm{~g} / \mathrm{L}$ and $50 \mathrm{~g} / \mathrm{L}$. Kinetic parameters of Saccharomyces cerevisiae in batch fermentation using pineapple peel waste as substrate were also studied. Growth kinetic parameter was determined by Monod equation. Growth rate specific maximum $\mu_{\max } 0.032$ jam $^{-1}$ and Monod constant $K_{s} 17.18 \mathrm{~g} / \mathrm{L}$.
\end{abstract}

Keywords: bioethanol, pineapple, batch, kinetic, Saccharomyces cerevisiae

\begin{abstract}
Abstrak
Pada penelitian ini akan dipelajari pengaruh konsentrasi gula total awal dari limbah kulit nanas pada profil pembentukan sel, konsumsi gula total dan produksi etanol. Fermentasi limbah kulit nanas dilakukan dengan sistem batch selama 60 jam dengan variasi gula total awal sebesar 30, 50 dan $70 \mathrm{~g} / \mathrm{L}$. Profil fermentasi batch menunjukkan bahwa konsentrasi gula total optimum adalah $70 \mathrm{~g} / \mathrm{L}$ yang menghasilkan produktivitas etanol tertinggi $0,617 \mathrm{~g} / \mathrm{L} / \mathrm{jam}$ bila dibandingkan dengan konsentrasi gula total $30 \mathrm{~g} / \mathrm{L}$ dan $50 \mathrm{~g} / \mathrm{L}$. Parameter kinetika dari Saccharomyces cerevisiae dalam fermentasi batch menggunakan limbah kulit nanas sebagai substrat juga dipelajari. Parameter kinetika pertumbuhan ditentukan dengan persamaan Monod. Kecepatan pertumbuhan spesifik maksimum $\mu_{\max } 0,032 \mathrm{jam}^{-1}$ dan konstanta Monod $K_{s}$ $17,18 \mathrm{~g} / \mathrm{L}$.
\end{abstract}

Kata kunci: bioetanol, nanas, batch, kinetika, Saccharomyces cereviseae

\section{PENDAHULUAN}

Etanol atau disebut dengan ethyl alcohol, atau EtOH, $\mathrm{CH}_{3}-\mathrm{CH}_{2}-\mathrm{OH}$. Manfaat dari etanol yaitu sebagai pelarut, germisida, kosmetik, minuman, bahan baku industri, bahan anti beku dan bahan bakar (McKetta et al., 1983). Etanol merupakan cairan volatile yang mudah terbakar, jernih dan tidak berwarna, berbau khas serta mudah larut dalam air (Kirk and Othmer, 1951). Bioetanol adalah biofuel cair yang dapat diproduksi dari bahan baku seperti biji-bijian, molasses, buah-buahan dan limbah atau biomassa dari tumbuhan sehingga dapat diperbaharui (Akpan et al., 2005). Bioetanol sebagai bahan bakar alternatif dapat memberikan kontribusi pada pengurangan emisi gas $\mathrm{CO}_{2}$ hasil pembakaran minyak bumi (Govindaswamy and Vane, 2007). Kandungan oksigen dalam bioetanol sebesar $35 \%$, yang akan mengurangi jumlah partikulat dan emisi $\mathrm{NO}_{\mathrm{x}}$ hasil pembakaran (Balat et al., 2008).

Nanas (Ananas comosus L. Merr.) adalah anggota dari family Bromeliaceae (monokotil) dan terdiri dari sekitar 200 species dengan produksi tahunan di seluruh dunia lebih dari 14 juta ton (Brat et al., 2004). Buah nanas berasal dari Brazil dan telah tersebar ke berbagai negara tropis dan subtropis di seluruh dunia (Dhar et al., 2008). Limbah pertanian merupakan sumber daya 
terbarukan dan dapat dimanfaatkan bagi bioteknologi dengan karakteristik tidak beracun, dalam jumlah besar, dapat diregenerasi, murah dan mampu mendukung pertumbuhan biomassa (Dhanasekaran et al., 2011). Pabrik pengalengan nanas hampir $67 \%$ dari buah yang terdiri dari $41 \%$ kulit, $6 \%$ jonggol atau inti, $20 \%$ mahkota tidak dimanfaatkan dan dibuang sebagai limbah yang menyebabkan pencemaran lingkungan (Medina and García, 2005). Kandungan bahan kering dari nanas sekitar $10 \%$ terdiri dari $96 \%$ bahan organik dan $4 \%$ bahan anorganik. Limbah nanas mengandung bahan organik dengan konsentrasi tinggi dan padatan tersuspensi. Selain dampak negatif yang ditimbulkan dari limbah nanas, terdapat potensi untuk direcycle menjadi bahan baku yang dikonversi menjadi produk yang lebih bernilai (Abdullah, 2007). Karakteristik limbah nanas yang digunakan pada penelitian ini dapat dilihat pada Tabel 1.

Tabel 1. Karakteristik Limbah Kulit Nanas yang Digunakan

\begin{tabular}{lc}
\hline \multicolumn{1}{c}{ Parameter } & Konsentrasi $(\mathbf{g} / \mathbf{L})$ \\
\hline Gula reduksi & 53,4 \\
Gula total & 79,1 \\
Kjeldahl nitrogen & 0,224 \\
pH & 4,5 \\
\hline
\end{tabular}

Saccharomyces cerevisiae atau disebut dengan baker's yeast merupakan mikroorganisme bersel tunggal berukuran 520 mikron. Saccharomyces cerevisiae sering digunakan dalam industri bioetanol (Prescott et al., 1959).

Kinetika fermentasi batch diperlukan untuk merancang ukuran fermentor dan peralatannya. Hasil kinetika fermentasi batch akan memperkirakan kecepatan pertumbuhan dan pembentukan produk (Russel, 1987). Model kinetika terdiri dari kinetika pertumbuhan sel, penggunaan substrat dan pembentukan produk (Pinelli et al., 1997). Laju pertumbuhan sel $\mu\left(\right.$ jam $\left.^{-1}\right)$ menurut Persamaan Monod (Keller and Dunn,1987) :

$$
\mu=\frac{\mu_{\max } \cdot S}{S+K_{S}}
$$

Dimana S adalah konsentrasi substrat $(\mathrm{g} / \mathrm{L}) ; \mathrm{K}_{\mathrm{s}}$ adalah konstanta Monod serta $\mu_{\max }$ adalah laju pertumbuhan spesifik maksimum. Fase pertumbuhan sel yeast pada fermentasi batch meliputi fase : lag; akselerasi; eksponensial; deselerasi; stasioner; kematian (Scraag, 1988). Fase pembentukan sel paling aktif yaitu pada fase eksponensial yang mana akan digunakan untuk penentuan parameter kinetika. Dari neraca massa komponen biomassa, substrat dan etanol serta substitusi Persamaan (1) maka didapatkan persamaan :

$$
\begin{array}{ll}
\frac{d X}{d t} & =\mu_{\max } \cdot\left(\frac{S}{K_{S}+S}\right) \cdot \mathrm{X} \\
\frac{d S}{d t} & =-\frac{1}{Y_{X / S}} \mu_{\max } \cdot\left(\frac{S}{K_{S}+S}\right) \cdot \mathrm{X} \\
\frac{d P}{d t} & =\mathrm{Y}_{\mathrm{p} / \mathrm{x}} \cdot \mu_{\text {max }} \cdot\left(\frac{S}{K_{S}+S}\right) \cdot \mathrm{X}
\end{array}
$$

Dimana $\mathrm{X}$ adalah konsentrasi sel $(\mathrm{g} / \mathrm{L}), \mathrm{S}$ adalah kosentrasi substrat $(\mathrm{g} / \mathrm{L}), \mathrm{P}$ adalah konsentrasi etanol $(\mathrm{g} / \mathrm{L}), \mathrm{Y}_{\mathrm{x} / \mathrm{s}}$ adalah yield biomassa pada penggunaan substrat ( $\mathrm{g}$ sel/g substrat), $\quad \mathrm{Y}_{\mathrm{p} / \mathrm{x}}$ adalah yield pembentukan etanol terhadap massa sel ( $\mathrm{g}$ etanol/ g sel) dan t adalah waktu (jam).

Persamaan diatas akan digunakan untuk menentukan parameter kinetika pertumbuhan yeast. Parameter kinetika akan diselesaikan dengan menggunakan MATLAB.

Tujuan dari penelitian ini adalah untuk mendapatkan konsentrasi gula total awal optimal yang dapat menghasilkan produktivitas etanol tertinggi serta dapat menentukan parameter kinetika pertumbuhan sel yeast fermentasi batch limbah kulit nanas.

\section{BAHAN DAN METODE PERCOBAAN}

Limbah kulit nanas akan digunakan sebagai substrat yang mengandung sumber karbon untuk fermentasi etanol, diperoleh dari Pasar Peterongan, Semarang. Limbah kulit nanas diekstrak dengan mencampur 250 gr kulit nanas dalam $350 \mathrm{~mL}$ air menggunakan blender selama 3 menit. Kemudian untuk menghilangkan padatan yang terkandung di dalam jus limbah kulit nanas, maka dilakukan penyaringan menggunakan kain. Cairan hasil penyaringan dipanaskan selama 5 menit yang akan membuat partikel mengendap pada suhu ruangan. Kemudian partikulat dihilangkan dengan sentrifugasi pada $4000 \mathrm{rpm}$ selama 15 menit. 
METANA, Vol. 10 No. 01, Juli 2014, Hal. 12 - 17

Supernatan dari limbah kulit nanas yang jernih kemudian disimpan pada suhu $-20{ }^{\circ} \mathrm{C}$ sampai digunakan (Tanaka et al., 1999).

Mikroorganisme yang digunakan adalah baker's yeast komersial Saccharomyces cerevisiae dengan merek Pakmaya (Pakmaya gold instant dry yeast, Istanbul, Turki).

Proses fermentasi pada beaker glass 1,5 $\mathrm{L}$ dengan volume substrat $1 \mathrm{~L}$ yang disterilisasi menggunakan metode pasteurisasi yaitu pemanasan dengan suhu $62^{\circ} \mathrm{C}$ selama 30 menit. Baker's yeast dengan konsentrasi 1 gr/L ditambahkan ke dalam fermentor dan nutrien urea sebesar $0,964 \mathrm{~g} / \mathrm{L}$. Proses fermentasi dilakukan selama 60 jam. Suhu fermentasi $28-30^{\circ} \mathrm{C}$ (suhu ruangan) serta nilai $\mathrm{pH}$ awal diatur 4,5. Sampel diambil sebanyak $10 \mathrm{~mL}$ dari fermentor untuk dianalisis konsentrasi gula total, konsentrasi sel dan konsentrasi etanol.

Konsentrasi sel diukur dengan menggunakan kurva densitas optik sebagai fungsi dari berat sel (dry cell weight). Dry cell weight ditentukan dengan sentrifugasi sampel pada $4000 \mathrm{rpm}$ selama 15 menit. Supernatan diambil dengan pipet dan pellet dicuci dua kali menggunakan air dan kemudian disentrifugasi kembali. Sel yang telah dicuci dikeringkan sampai beratnya konstan pada suhu $60^{\circ} \mathrm{C}$. Densitas optik diukur menggunakan Spektrofotometer Optima SP-300 pada 620 nm (Aeschlimann and Stockar, 1987; Monteagudo et al., 1997). Dry cell weight diestimasi menggunakan kurva standar. Konsentrasi gula total diukur dengan metode DNS dan diukur absorbansi larutan sampel pada $540 \mathrm{~nm}$ (Ceirwyn, 1995). Konsentrasi dari gula total diukur menggunakan kurva standard dari konsentrasi glukosa. Konsentrasi etanol diukur dengan menggunakan acidified dichromate dan dibaca absorbansinya pada panjang gelombang $600 \mathrm{~nm}$ (Crowell and Ough, 1979).

\section{HASIL PERCOBAAN PEMBAHASAN}

DAN

Limbah kulit nanas yang digunakan mengandung tiga jenis gula yaitu sukrosa, glukosa dan fruktosa. Dalam penelitian ini perhitungan konsentrasi gula dilakukan dalam bentuk gula total, dan divariasikan konsentrasinya $30 \mathrm{~g} / \mathrm{L}, 50 \mathrm{~g} / \mathrm{L}$ dan $70 \mathrm{~g} / \mathrm{L}$. Profil pembentukan sel, konsumsi gula total dan pembentukan etanol dapat dilihat pada Gambar 1., Gambar 2. dan Gambar 3.

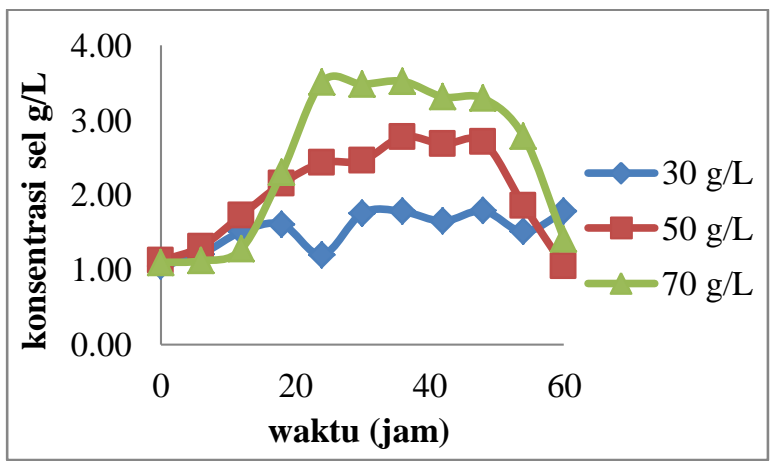

Gambar 1. Profil pertumbuhan sel pada konsentrasi gula total yang berbeda

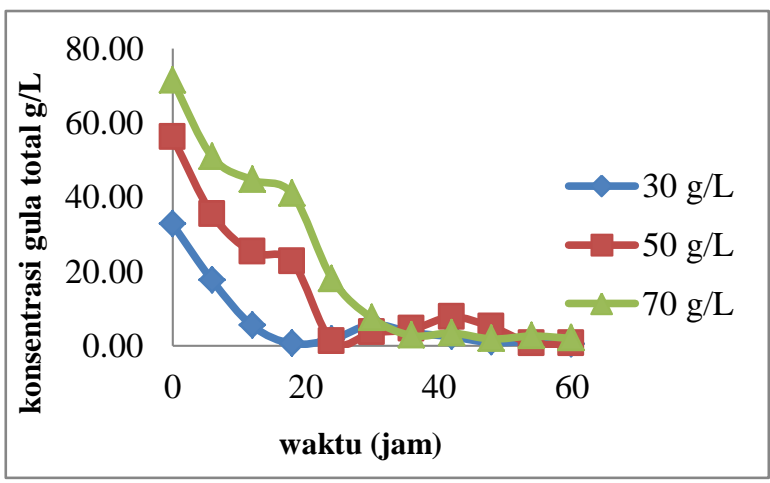

Gambar 2. Profil penggunaan substrat pada konsentrasi gula total yang berbeda

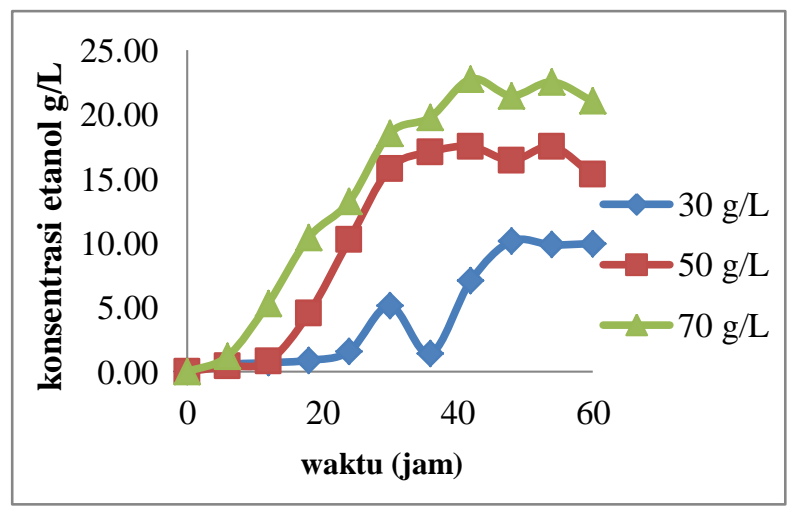

Gambar 3. Profil produksi etanol pada konsentrasi gula total yang berbeda 
Gambar 1. menunjukkan kurva pembentukan sel pada sistem batch. Ketiga kurva pertumbuhan sel dengan konsentrasi gula total awal berbeda, memiliki profil yang hampir sama yaitu fase lag, fase eksponensial dan fase stasioner. Konsentrasi gula total awal $30 \mathrm{~g} / \mathrm{L}$ pertumbuhan selnya tidak optimal seperti pada konsentrasi gula total awal $50 \mathrm{~g} / \mathrm{L}$ dan $70 \mathrm{~g} / \mathrm{L}$. Profil konsumsi gula (Gambar 2.) dan produksi etanol (Gambar 3.) menunjukkan bahwa dengan naiknya konsentrasi gula total awal maka akan semakin banyak pula etanol yang dihasilkan oleh yeast, akan tetapi konsentrasi gula total awal tertinggi memiliki batas tertentu sesuai dengan hasil penelitian yang dilakukan oleh (Hunag et al., 2012). Yield etanol terhadap substrat tertinggi yaitu $0,259 \mathrm{~g} / \mathrm{g}$ diperoleh pada konsentrasi gula total awal $70 \mathrm{~g} / \mathrm{L}$. Dengan membandingkan profil pembentukan sel dan pembentukan produk menunjukkan bahwa fermentasi batch limbah kulit nanas diklasifikasikan sebagai growth associated dimana etanol diproduksi secara simultan dengan pertumbuhan sel. Dari Gambar 4. dapat dilihat bahwa produktivitas etanol paling tinggi sebesar $0,617 \mathrm{~g} / \mathrm{L} / \mathrm{jam}$ pada jam ke-30 dengan konsentrasi gula total awal 70 $\mathrm{g} / \mathrm{L}$. Dari penjelasan di atas maka dapat disimpulkan konsentrasi gula total paling optimum untuk fermentasi batch limbah kulit nanas adalah sebesar $70 \mathrm{~g} / \mathrm{L}$.

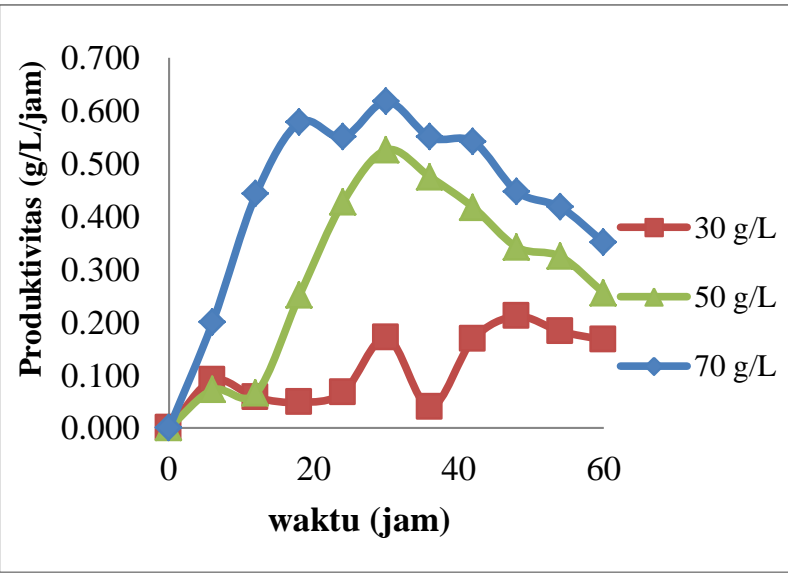

Gambar 4. Produktivitas etanol

Parameter kinetika fermentasi batch limbah kulit nanas dengan konsentrasi gula total awal sebesar $70 \mathrm{~g} / \mathrm{L}$ dihitung dengan Persamaan (4), (5) dan (6) dengan
MATLAB. Hasil perhitungan parameter kinetika disajikan pada Tabel 2.

Tabel 2. Parameter kinetika untuk produksi etanol pada fermentasi batch limbah kulit nanas

\begin{tabular}{|c|c|c|}
\hline Parameter & $\begin{array}{c}\text { (Penelitian } \\
\text { ini, 2014) }\end{array}$ & $\begin{array}{l}\text { (Shafaghat } \\
\text { et al., 2009) }\end{array}$ \\
\hline$\mu_{\max }\left(\mathrm{jam}^{-1}\right)$ & 0,032 & 0,65 \\
\hline $\mathrm{K}_{\mathrm{s}}(\mathrm{g} / \mathrm{L})$ & 17,18 & 11,39 \\
\hline $\mathrm{Y}_{\mathrm{x} / \mathrm{s}} \quad(\mathrm{g}$ & 0,016 & 0,043 \\
\hline $\begin{array}{l}\text { substrat) } \\
\alpha \text { (g produk/g sel) }\end{array}$ & 18,85 & - \\
\hline
\end{tabular}

Penelitian yang dilakukan oleh Shafaghat et al. (2009) dilakukan pada substrat glukosa dengan konsentrasi awal sebesar $35 \mathrm{~g} / \mathrm{L}$. Hasil parameter kinetika yang berbeda disebabkan substrat yang digunakan pada penelitian ini lebih kompleks karena mengandung tiga jenis gula yaitu sukrosa, glukosa dan fruktosa.

\section{KESIMPULAN}

Pemanfaatan limbah kulit nanas untuk produksi bioetanol sangat menjanjikan. Dalam penelitian ini diperoleh konsentrasi gula total awal terbaik sebesar $70 \mathrm{~g} / \mathrm{L}$, yang menghasilkan konsentrasi etanol tertinggi sebesar 18,52 g/L. Semakin tinggi konsentrasi gula maka akan semakin tinggi pula konsentrasi etanol yang dihasilkan. Produktivitas etanol maksimum dengan menggunakan konsentrasi gula total $70 \mathrm{~g} / \mathrm{L}$.

\section{DAFTARPUSTAKA}

Abdullah. (2007), "Solid and liquid pineapple waste utilization for lactic acid fermentation usingLactobacillus delbueckii", Jurnal Reaktor, Vol. 11 No. 1, pp. $50-52$.

Aeschlimann, A. and Stockar, U.V. (1987), "The production of lactic acid from Whey permeate.", In Abstract of Fourth European Congress on Biotechnology, Vol. 2, pp. 132-135.

Akpan, U.G., Kovo, A.S., Abdullahi, M. and Ijah, J.J. (2005), “The production of 
METANA, Vol. 10 No. 01, Juli 2014, Hal. 12 - 17

ethanol from maize cobs and groundnut shells", AU J. Technol, Vol. 9, pp. 106-110.

Balat, M., Balat, H. and Oz, C. (2008), "Progress in bioethanol processing”, Progress in Energy and Combustion Science, Vol. 34, pp. 551-573.

Brat, P., Hoang, L.N.T., Soler, A., Reynes, M. and Brillouet, J.M. (2004), "Physicochemical characterization of new pineapple hybrid”, Journal of Agricultural and Food Chemistry, Vol. 52, pp. 6170-6177.

Ceirwyn, S.J. (1995), Analytical Chemistry Food, Blackie Academic \& Professional, London, pp. 84-125.

Crowell, E.A. and Ough, C.S. (1979), “ $A$ modified procedure for alcohol determination by dichromate oxidation", Am. J. Enol. Vitic, Vol. 30 No. 1, pp. 61-63.

Dhanasekaran, D., Lawanya, S., Saha, S., Thajuddin, N. and Panneerselvam, A. (2011), "Production of single cell protein from pineapple waste using yeast.", Innovative Romanian Food Biotechnology., Vol. 8, pp. 26-32.

Dhar, M., Rahman, S.M. and Sayem, S.M. (2008), "Maturity and post harvest study of pineapple with quality and shelf life under red soil.", International Journal of Suistainable Crop Production., Vol. 3 No. 2, pp. 69-75.

Govindaswamy, S. and Vane, L.M. (2007), "Kinetics of growth and ethanol production on different carbon substrate using genetically engineered xylose-fermenting yeast”, Bioresource Technol, Vol. 98, pp. 677-685.

Hunag, W.-H., Shieh, G.S. and Wang, F.-S. (2012), “Optimization of fed-batch fermentation using mixture of sugars to produce ethanol", Journal of the Taiwan Institute of Chemical Engineers, Taiwan Institute of Chemical Engineers, Vol. 43 No. 1, pp. 1-8

Keller, R. and Dunn, I. (1987), “Fed-batch microbial culture: models, errors and application", J. App. Chem. Tech. Biotechnol., Vol. 28, pp. 508514.

Kirk, R.E. and Othmer, R.F. (1951), Encyclopedia of Chemical Technology, John Wiley and Sons Ltd., Canada, 9thed

McKetta, J., J. and Cunningham, W.A. (1983), Encyclopedia of Chemical Processing and Design, Marcel Dekker, Inc., New York and Bessel.

Medina, J.D.L.C. and García, H.S. (2005), "Post-harvest Operations".

Monteagudo, J.M., Rodriguez, L., Rincon, J. and Fuertes, J. (1997), "Kinetics of lactic acid fermentation Lactobacillus delbrueckii grown on beet molasses", J. Chem. Tech. Biotechnology, Vol. 68, pp. 271-276.

Pinelli, D., Vara, A.G. and Magelli, F. (1997), “Assement of kinetics models for the production of $D$ and $L$ lactic acid isomer by $L$. casei and $L$. cornyniformis in continuous fermentation", Journal of Fermentation and Bioengineering, Vol. 83 No. 2, pp. 209-212.

Prescott, Cate, S. and Dunn, C.G. (1959), Industrial Microbiology, McGrawHill Book Company, Inc., New York.

Russel, P.D. (1987), Fermentation and bioreactor design, Elsevier apllied science, London

Scraag, A.H. (1988), Biotechnology for Engineers, Biological System in Technological Processes, John Wiley and Sons Ltd., England. 
Shafaghat, H., Najafpor, G.D., Rezaei, P.S. and Sharifzadeh, M. (2009), "Growth kinetics and ethanol productivity of Saccharomyces cerevisiae PTCC 24860 on various carbon sources", World Applied Sciences Journal, Vol. 7 (2), pp. 140-144.

Tanaka, K., Hilary, Z.D. and Ishizaki, A. (1999), "Investigation of the utility of pineapple juice and waste as material low-cost substrate for ethanol fermentation by Zymomonas mobilis", Journal of Biochemical and Bioengineering, Vol. 87 No. 5, pp. 642-646 